\title{
Predicting College Students' Future Intentions to Engage in Public-Sphere Water Conservation Behaviors
}

\author{
A. Wise ${ }^{1}$, D. Johnson ${ }^{2}$, G. Wardlow ${ }^{3}$, K. Jogan ${ }^{4}$
}

\section{Abstract}

The purpose of this study was to describe selected college students' ( $N=252$ ) perceptions of and future intentions (FI) to engage in public-sphere water conservation behaviors, and to determine if $\mathrm{FI}$ could be predicted by a single or linear combination of student demographic characteristics and latent variables. A majority of respondents agreed a growing population will negatively affect water quantity $(90.5 \%)$ and there is a need for water resource management (85.6\%). A majority disagreed or strongly disagreed that they (53.4\%), their family $(57.1 \%)$, or their friends $(67.5 \%)$ practiced water conservation, or that people in their hometowns were concerned about local water availability (78.1\%). A majority agreed they would engage in four of five public-sphere water conservation behaviors in the future: support water conservation programs $(86.4 \%)$, care more deeply about water conservation (81.2\%), join a water conservation organization (79.2\%), and vote for stricter water use laws (55.0\%). Fewer than one-half agreed or strongly agreed they would donate money to support water conservation (45.8\%). Responses to statements concerning water conservation were factor analyzed and two factors were extracted: lack of agency (LA) and subjective norms (SN). A linear combination of gender, LA, and SN explained $36.7 \%$ of the variance in FI.

\section{Keywords}

subjective norms, theory of planned behavior, environment

1. Austin Wise, Ph.D. Student, University of Nebraska-Lincoln, 322 Bessey Hall, Lincoln NE 68588-0340, awise2@huskers.unl.edu, (iD https://orcid.org/0000-0002-9388-4946

2. Donald Johnson, Professor, University of Arkansas, E108 AFLS Building, Fayetteville, AR 72701, dmjohnso@uark.edu, iD https://orcid.org/0000-0003-2592-654X

3. George Wardlow, Professor and Head, University of Arkansas, E108 AFLS Building, Fayetteville, AR 72701, wardlow@uark.edu, iD https://orcid.org/0000--0001-5701-8250

4. Kathi Jogan, Instructor, University of Arkansas, 1120 W. Maple St., Fayetteville, AR 72701, kjogan@uark.edu, 


\section{Introduction and Problem Statement}

Earth's surface is over $75 \%$ water, however only about $2.5 \%$ of that is freshwater and even less is available for human use (United States Geological Survey, 2018). Certainly, freshwater is a valuable and limited resource. Thus, it is important to consider the conservation of such limited resources and to promote responsible use practices and policies (Chaudhary et al., 2017).

Water conservation behaviors have been categorized as either private- or public-sphere behaviors (Stern, 2002). Private-sphere behaviors refer to actions taken to conserve water on an individual or household level, such as use of low-flow shower heads or installation of high efficiency toilets. Public-sphere water conservation behaviors refer to civic engagement in proconservation actions designed to influence public policies relative to water conservation. Such behaviors include voting, membership in water conservation organizations, and support for water conservation policies (Stern, 2002).

Older adults, females, persons living in single-family residences, and those holding more liberal political orientations are more likely to engage in private-sphere water conservation behaviors (Arnocky \& Stroink, 2011; Chaudhary et al., 2018; Clark \& Finley, 2007; Larson et al., 2011). Individuals with higher levels of education (Larson \& Larch, 2010) and those with college majors in natural resources (Arnocky \& Stroink, 2011) are more likely to engage in broader proenvironmental public-sphere behaviors. Koehler and Koontz (2008) found males, those in careers related to the environment, those from rural areas, and those with higher levels of political involvement were more likely to be active in collaborative watershed groups, one type of public-sphere water conservation behavior.

This research sought to identify predictors of college students' future intentions (FI) to engage in public-sphere water conservation behaviors. This research is particularly important given the higher level of involvement by college graduates in voting and public policy advocacy (Brand, 2010), two primary public-sphere behaviors (Stern, 2002).

\section{Theoretical and Conceptual Framework}

The research was guided by the Ajzen's (1991) Theory of Planned Behavior (TPB). The TPB attempts to predict and explain human behavior based on three determinants: attitude, subjective norms and perceived behavioral control (see Figure 1). Attitude refers to how favorable an individual's opinion or evaluation is for a given behavior and as determined by the individual. Subjective norms refer to perceived social pressure to perform or not to perform the behavior, and perceived behavioral control refers to the perceived ease or difficulty of performing the target behavior (Ajzen, 1991). Within the context of this study, we sought to predict future intentions to engage in public-sphere water conservation behaviors. Respondent demographic characteristics (age, gender, academic classification, major, home community, and political orientation) previously found to be related to water conservation attitudes and behaviors were also included in the theoretical model. 


\section{Figure 1}

Model of Adapted Theory of Planned Behavior

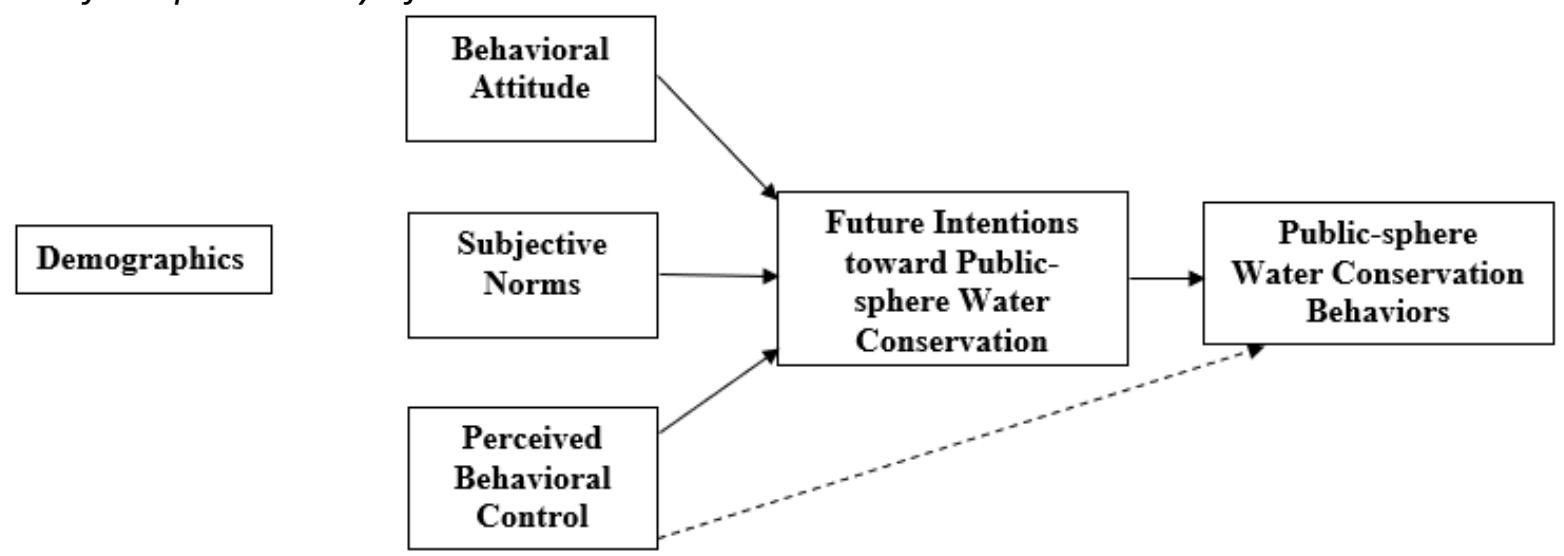

Note. Adapted from "The Theory of Planned Behavior," by I. Ajzen, 1991, Organizational Behavior and Human Decision Processes, 50, 179-211. (https://doi.org/10.1016/07495978(91)90020-T).

According to Pradhananga et al. (2015), "Socio-demographic characteristics such as age, income, and education provide important information about who [italics in original] commonly engages or does not engage in water resource decision making, but socio-demographics do not explain what [italics in original] motivates engagement" (p. 1602). This view was supported by Larson et al. (2011). Mancha and Yoder (2015) suggested that people's intended behaviors were influenced by subjective norms. They concluded that if the people surrounding the respondent expected that individual to behave in a specific way then that was likely to influence any intentions that individual may have towards the environment. Among the few studies in this area, self-efficacy (Martinez \& McMullin, 2004) and subjective norms (Fielding et al., 2008) were found to be strong predictors of public-sphere environmental behaviors. In one of the few studies testing these relationships specifically in the realm of water conservation, Pradhananga et al. (2015) found that subjective norms had a significant effect on landowners' public-sphere water conservation behaviors.

\section{Purpose}

The purpose of this study was to assess undergraduate students' perceptions of water conservation and their future intentions toward public-sphere water conservation behaviors.

1. Describe students' perceptions of selected aspects of water conservation;

2. Identify and name the latent factor structure underlying students' perceptions about selected aspects of water conservation;

3. Describe students' future intentions to engage in public-sphere water conservation behaviors;

4. Determine the relationships between selected student demographic characteristics (age, gender, community type, academic classification, major, and political orientation), the 
identified latent factors, and future intentions concerning public-sphere water conservation behaviors; and

5. Determine if a single or linear combination of student demographic characteristics and identified latent factors could explain a significant $(p<.05)$ portion of the variance in students' future intentions concerning public-sphere water conservation behaviors.

\section{Methods}

The population for this study was the 27,559 undergraduate students enrolled at the University of Arkansas during the Spring 2020 term (University of Arkansas, 2019). Based on an anticipated effect size of $f^{2}=0.15$ and a statistical power of .95, an alpha of .05, and 10 potential predictors, the minimum sample size was calculated to be 172 subjects using G*Power 3.1.9.6 (Faul et al., 2007).

After university IRB approval, all undergraduate courses with enrollments of 30 students or higher were identified using a spreadsheet provided by the Registrar's Office. Courses were then stratified as agriculture or non-agriculture courses based on their alpha codes, and 10 courses were randomly selected from each stratum. Instructors of each selected course were contacted and asked to allow their students to participate. All courses switched to remote instruction due to the coronavirus pandemic within a week after this initial contact, and only six instructors agreed to participate. Additional non-random sampling procedures were used to ensure adequate responses to achieve the study objectives. Thus, due to circumstances dictated by the novel coronavirus pandemic, a randomly selected sample of students was not surveyed and no generalizations beyond these respondents are warranted.

The survey instrument was developed by the researcher and refined during a cognitive interview with a University of Arkansas faculty member specializing in quantitative social science survey development. Face and construct validity were established by a panel of four faculty members with expertise in quantitative social science research and natural resource conservation. The survey contained three sections. Section one determined respondents' agreement with 16 statements about water resources using a 1 to 4 Likert-type scale ( $1=$ strongly disagree and 4 = strongly agree). Section two contained five items concerning respondents' future intentions (FI) concerning public-sphere water conservation, measured on the same 1 to 4 Likert-type scale ( 1 = strongly disagree and 4 = strongly agree). These items were developed by the researchers based on Stern's (2002) definition of public-sphere environmental behaviors. Section three contained six items to determine respondent demographic characteristics of age, gender, academic classification, major (agriculture or nonagriculture), home community (rural or metro), and political orientation (very conservative to very liberal). The post-hoc coefficient alpha reliabilities for the two latent factors derived from Part one of the instrument were .73 and .75; the coefficient alpha reliability of Part two was .85.

Data were analyzed using descriptive statistics and ordinary least-squares multiple regression. Exploratory factor analysis with a promax rotation was used to identify latent constructs 
underlying student responses to the 16 water use and conservation statements. The number of meaningful factors to retain was determined based on the scree plot of eigenvalues, the proportion of variance explained by each factor, and by the interpretability of the resulting factors (Hatcher, 1994). Factors were deemed interpretable if at least three items loaded on each factor (minimum loading $=.40$ ), the variables loading on each factor shared some conceptual meaning, and items loading on one factor had near-zero loadings on other factors (Hatcher, 1994). Prior to multiple regression analysis, data were examined for outliers and influential observations and violations of assumptions of linearity of the predictor and criterion variables, multicollinearity, normality of residuals, and homogeneity of the variance of the residuals (Field and Miles, 2012). Two outliers were identified (studentized residuals $\geq|3.0|$ ) and removed from the data set (Field \& Miles, 2012). Linearity of continuous predictors and the criterion variable was verified using bivariate scatterplots. Variance inflation factors of $<5.0$ indicated the multicollinearity was not a threat (Field \& Miles, 2012). The Shapiro-Wilk test was used to test the assumption of normality of residuals and results indicated this assumption was not violated, $w=0.99, p=.13$. Homogeneity of variance of the residuals was assessed by White's test and the results indicated this assumption was not violated, $\chi^{2}(18)=20.91, p=.28$.

\section{Findings}

Of the students $(N=252)$ responding to this survey, $40.9 \%$ identified as male, $58.7 \%$ as female, and $0.4 \%$ did not disclose their gender identity. A slight majority of respondents were either freshmen (28.6\%) or sophomores (30.6\%), majoring in agriculture $(56.8 \%)$, coming from rural $(52.4 \%)$ areas, and identifying their political views as either conservative $(32.3 \%)$ or very conservative (24.3\%). The mean age of respondents was 20.38 years $(S D=2.25)$. A majority indicated they paid their own water bill, either as a separate bill $(29.0 \%)$ or as part of their rent (29.0\%).

As shown in Table 1, more than one-half of respondents agreed or strongly agreed that a growing population will negatively affect water quantity $(90.5 \%)$, there is a need for water resource management (85.6\%), the respondent could easily reduce water use if they wanted (76.0\%), that people they spend time with do not care whether the respondent conserved water or not $(67.0 \%)$, that their personal water use had little impact on regional water quantity $(54.7 \%)$, and that conserving water is easier for the respondent than for others. Conversely, more than one-half of respondents disagreed or strongly disagreed that they (53.4\%), their family (57.1\%), or their friends (67.5\%) practiced water conservation, or that people in their hometowns were concerned about local water quantity (78.1\%). Respondents disagreed or strongly disagreed they felt social pressure to conserve water $(78.9 \%)$ or that the cost of water caused them to use less (74.6\%). Almost one-half of respondents agreed or strongly agreed that freshwater was a quickly renewable resource (42.1\%). 
Table 1

Student Agreement with Selected Statements Concerning Water Use and Conservation

\begin{tabular}{|c|c|c|c|c|c|}
\hline \multirow[b]{2}{*}{ Statement } & \multirow[b]{2}{*}{$n$} & \multicolumn{4}{|c|}{ Level of agreement } \\
\hline & & $\begin{array}{l}\text { Strongly } \\
\text { disagree (\%) }\end{array}$ & $\begin{array}{l}\text { Disagree } \\
(\%)\end{array}$ & $\begin{array}{l}\text { Agree } \\
(\%)\end{array}$ & $\begin{array}{l}\text { Strongly } \\
\text { agree (\%) }\end{array}$ \\
\hline $\begin{array}{l}\text { A growing population will negatively } \\
\text { affect water quantity }\end{array}$ & 252 & 2.0 & 7.5 & 56.8 & 33.7 \\
\hline $\begin{array}{l}\text { There is a need for water resource } \\
\text { management }\end{array}$ & 251 & 10.8 & 3.6 & 44.6 & 41.0 \\
\hline $\begin{array}{l}\text { If I wanted to, I could easily cut } \\
\text { down my water use }\end{array}$ & 250 & 2.4 & 21.6 & 61.6 & 14.4 \\
\hline $\begin{array}{l}\text { The people I spend time with do not } \\
\text { care whether I conserve water }\end{array}$ & 252 & 3.6 & 29.4 & 59.1 & 7.9 \\
\hline $\begin{array}{l}\text { My water use has little impact on } \\
\text { water quantity in my region }\end{array}$ & 252 & 7.9 & 37.3 & 46.8 & 7.9 \\
\hline $\begin{array}{l}\text { Conserving water is easier for me } \\
\text { than for others }\end{array}$ & 252 & 4.8 & 44.4 & 42.1 & 8.7 \\
\hline I am engaged in water conservation & 251 & 8.4 & 45.0 & 39.4 & 7.2 \\
\hline $\begin{array}{l}\text { My family practices water } \\
\text { conservation }\end{array}$ & 252 & 10.7 & 46.4 & 37.3 & 5.6 \\
\hline $\begin{array}{l}\text { Freshwater is a quickly renewable } \\
\text { resource }\end{array}$ & 252 & 14.7 & 43.2 & 38.1 & 4.0 \\
\hline $\begin{array}{l}\text { My friends practice water } \\
\text { conservation }\end{array}$ & 252 & 13.9 & 53.6 & 30.6 & 2.0 \\
\hline $\begin{array}{l}\text { The cost of water causes me to use } \\
\text { less in my daily life }\end{array}$ & 252 & 20.6 & 54.0 & 22.6 & 2.8 \\
\hline $\begin{array}{l}\text { It would make no difference if I } \\
\text { conserved more household water }\end{array}$ & 252 & 54.2 & 35.5 & 8.4 & 2.0 \\
\hline $\begin{array}{l}\text { People in my hometown are } \\
\text { concerned about local water } \\
\text { quantity }\end{array}$ & 252 & 20.2 & 57.9 & 18.1 & 3.9 \\
\hline $\begin{array}{l}\text { I feel social pressure to conserve } \\
\text { water }\end{array}$ & 251 & 19.1 & 59.8 & 17.5 & 3.6 \\
\hline $\begin{array}{l}\text { Water resource management is less } \\
\text { important now than it was in the } \\
\text { past }\end{array}$ & 252 & 39.3 & 44.4 & 11.9 & 4.4 \\
\hline $\begin{array}{l}\text { It would make no difference if } \\
\text { everyone conserved more } \\
\text { household water }\end{array}$ & 251 & 54.2 & 35.5 & 8.4 & 2.0 \\
\hline
\end{tabular}

Exploratory factor analysis identified two factors (see Table 2) that explained $93.0 \%$ of the variance in the original 16 items. Four items loaded on Factor 1, six items loaded on Factor 2, and six items did not load on any factor. Based on the highest loading items in each factor (Yong 
and Pearce, 2013), the factors were named "lack of agency" (LA) and "subjective norms" (SN). The coefficient alpha reliability estimates for LA and SN were .75 and .73, respectively.

\section{Table 2}

Summary of Items, Loadings, and Factor Reliabilities for the Two-Factor Solution for Agreement with Selected Statements Concerning Water Use and Conservation $(n=246)$

\section{Loading}

\begin{tabular}{|c|c|c|}
\hline Item & Factor 1 & Factor 2 \\
\hline \multicolumn{3}{|l|}{ Factor 1: Lack of Agency (coefficient alpha $=.75$ ) } \\
\hline $\begin{array}{l}\text { It would make no difference if everyone conserved more } \\
\text { household water }\end{array}$ & .86 & .22 \\
\hline $\begin{array}{l}\text { It would make no difference if I conserved more household } \\
\text { water }\end{array}$ & .72 & .08 \\
\hline $\begin{array}{l}\text { Water resource management is less important now than it was } \\
\text { in the past }\end{array}$ & .55 & .01 \\
\hline Freshwater is a quickly renewable resource & .51 & .06 \\
\hline \multicolumn{3}{|l|}{ Factor 2: Subjective Norms (coefficient alpha $=.73$ ) } \\
\hline My friends practice water conservation & .03 & .71 \\
\hline My family practices water conservation & .02 & .68 \\
\hline I feel social pressure to conserve water & .19 & .57 \\
\hline I am engaged in water conservation & -.24 & .50 \\
\hline People in my hometown are concerned about water quantity & .18 & .49 \\
\hline Conserving water is easier for me than for others & .03 & .44 \\
\hline
\end{tabular}

Note. Factor loadings greater than .40 are shown in bold.

Respondents were asked their level of agreement they would engage in five future publicsphere water conservation behaviors. As shown in Table 3, over one-half of all respondents agreed or strongly agreed they would engage in four of the five public-sphere activities in the future: support water conservation programs (86.4\%), care more deeply about water conservation (81.2\%), join a water conservation organization (79.2\%), and vote for stricter water use laws (55.0\%). Slightly fewer than one-half agreed or strongly agreed they would donate money to support water conservation (45.8\%). 


\section{Table 3}

Student Agreement They Will Participate in Public-Sphere Behaviors Related to Water Conservation in the Future

\begin{tabular}{|c|c|c|c|c|c|}
\hline \multirow[b]{2}{*}{ Behavior } & \multirow[b]{2}{*}{$\mathrm{n}$} & \multicolumn{3}{|c|}{ Level of agreement } & \multirow[b]{2}{*}{$\begin{array}{l}\text { Strongly } \\
\text { agree (\%) }\end{array}$} \\
\hline & & $\begin{array}{l}\text { Strongly } \\
\text { disagree (\%) }\end{array}$ & $\begin{array}{l}\text { Disagree } \\
(\%)\end{array}$ & $\begin{array}{l}\text { Agree } \\
(\%)\end{array}$ & \\
\hline $\begin{array}{l}\text { Support water conservation } \\
\text { programs }\end{array}$ & 251 & 2.4 & 11.2 & 66.9 & 19.5 \\
\hline $\begin{array}{l}\text { Care more deeply about water } \\
\text { conservation }\end{array}$ & 251 & 2.4 & 16.3 & 64.1 & 17.1 \\
\hline $\begin{array}{l}\text { Join a water conservation } \\
\text { organization }\end{array}$ & 251 & 3.2 & 17.5 & 64.1 & 15.1 \\
\hline Vote for stricter water use laws & 251 & 8.8 & 36.2 & 454 & 9.6 \\
\hline $\begin{array}{l}\text { Donate money to support water } \\
\text { conservation }\end{array}$ & 251 & 6.8 & 47.4 & 38.6 & 7.2 \\
\hline
\end{tabular}

The five activities in Table 2 were summed and a mean score was calculated as an overall measure of future intentions (FI) to engage in public-sphere water conservation behaviors. The mean FI score was $2.79(S D=0.55)$ on a 1 to 4 scale, indicating overall agreement.

As shown in Table 4, five variables were significantly $(p<.05)$ correlated with FI. The descriptors proposed by Davis (1971) were used to characterize the magnitude of all correlations. Political orientation and LA had significant, low negative correlations with FI, indicating that political conservatives and those with higher LA scores had lower FI scores. Age and SN had significant, low to moderate, respectively, positive correlations with $\mathrm{FI}$, indicating that older students and students with higher SN scores had higher FI scores. The intercorrelations between potential predictor variables ranged from negligible to substantial. Classification and age were substantially correlated (as expected), and both had low negative correlations with LA. Political orientation had a significant low positive correlation with LA and with major. Finally, there was a low positive correlation between gender and LA. No other correlations were statistically significant. 


\section{Table 4}

Intercorrelations between Demographic Characteristics, LA and SN Factors, and FI

\begin{tabular}{|c|c|c|c|c|c|c|c|c|c|}
\hline Variable & $\mathrm{X} 1$ & $\times 2$ & X3 & $\mathrm{X} 4$ & $\times 5$ & $\mathrm{x} 6$ & $\mathrm{X7}$ & $\mathrm{x} 8$ & $\times 9$ \\
\hline$\overline{\text { Gender }^{\mathrm{a}}(\mathrm{X} 1)}$ & 1.0 & $.07^{\mathrm{eNS}}$ & $-.23^{* * *}$ & $-.04^{\mathrm{eNS}}$ & $.31^{\mathrm{e}^{* * *}}$ & $.06^{\mathrm{fNS}}$ & $.17^{f^{* *}}$ & $.08^{\mathrm{fNS}}$ & $-.13^{f^{*}}$ \\
\hline Classification ${ }^{b}(X 2)$ & & 1.0 & $.03^{\mathrm{eNS}}$ & $.00^{\mathrm{eNS}}$ & $-.05^{\mathrm{eNS}}$ & $.61^{\mathrm{g}^{* * *}}$ & $-.21^{\mathrm{g}^{* * *}}$ & $-.04^{\mathrm{gNS}}$ & $-.01^{\mathrm{gNS}}$ \\
\hline Major (X3) & & & 1.0 & $.09^{\mathrm{eNS}}$ & $-.12^{\mathrm{e}^{*}}$ & $-.04^{\mathrm{gNS}}$ & $.10^{\mathrm{gNS}}$ & $-.09^{g N S}$ & $-.07^{\mathrm{gNS}}$ \\
\hline Community $^{c}(\mathrm{X} 4)$ & & & & 1.0 & $-.01^{\mathrm{fNS}}$ & $.01^{\mathrm{gNS}}$ & $-.01^{\mathrm{gNS}}$ & $-.01^{\mathrm{gNS}}$ & $.01^{\mathrm{gNS}}$ \\
\hline Political orient. ${ }^{d}$ (X5) & & & & & 1.0 & $-.08^{\mathrm{gNS}}$ & $.24^{\mathrm{g}^{* * *}}$ & $-.09^{g N S}$ & $-.15^{g^{*}}$ \\
\hline Age (X6) & & & & & & 1.0 & $-.26^{\mathrm{h}^{* * *}}$ & $.06^{\mathrm{hNS}}$ & $.16^{\mathrm{h} * *}$ \\
\hline LA (X7) & & & & & & & 1.0 & $.05^{\mathrm{hNS}}$ & $-.29^{h^{* * *}}$ \\
\hline SN (X8) & & & & & & & & 1.0 & $.49^{\mathrm{h}^{* * *}}$ \\
\hline $\mathrm{FI}(\mathrm{X9})$ & & & & & & & & & 1.0 \\
\hline
\end{tabular}

${ }^{\mathrm{a}}$ Coded as female $=0$ and male $=1 .{ }^{\mathrm{b}}$ Coded as $0=$ freshman of sophomore and $1=$ junior or senior. ${ }^{c}$ Coded as $0=$ rural and $1=$ metro. ${ }^{d}$ Coded as $0=$ not conservative and $1=$ conservative. ${ }^{\mathrm{e}}$ phi coefficient. ${ }^{\mathrm{f}}$ point biserial correlation. ${ }^{\mathrm{g}}$ biserial correlation. ${ }^{\mathrm{h}}$ Pearson correlation.

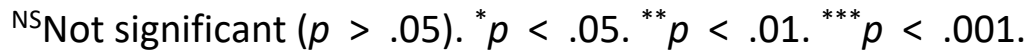

The final objective sought to determine if a single or linear combination of student demographic characteristic or LA and SN factors could explain a significant $(p<.05)$ portion of the variance in FI. Based on the results of bivariate analysis, gender, political orientation, age, $\mathrm{LA}$, and $\mathrm{SN}$ were included as potential predictors in the regression equation.

The regression model was significant, $F(5,241)=28.62, p<.001$. Three variables, gender, LA, and SN entered into the model (see Table 5) and explained $36.7 \%$ of the variance in $\mathrm{FI}$. The regression coefficients for both gender and LA were negative, indicating lower $\mathrm{FI}$ scores for males and respondents with higher LA scores. The positive regression coefficient for SN indicated respondents who higher subjective norms related to water conservation also had higher FI scores. The Cohen's $f^{2}$ of 0.58 , represented a large effect size (Cohen, 1988).

\section{Table 5}

Regression Model Predicting FI from Political Orientation, Age, Gender, LA, and SN

\begin{tabular}{llrrrr}
\hline Variable & $d f$ & \multicolumn{1}{l}{$B$} & \multicolumn{1}{l}{ SE } & \multicolumn{1}{l}{$p$} \\
\hline Intercept & 1 & 1.59 & 0.33 & 4.84 & $<.001$ \\
Political orientation & 1 & 0.01 & 0.06 & 0.09 & .929 \\
Age & 1 & 0.02 & 0.01 & 1.42 & .157 \\
Gender & 1 & -0.15 & 0.06 & -2.53 & .012 \\
LA & 1 & -0.25 & 0.05 & -4.86 & $<.001$ \\
SN & 1 & 0.60 & 0.06 & 10.10 & $<.001$ \\
\hline
\end{tabular}

Squared semi-partial correlations were calculated for gender, LA, and SN to determine the amount of unique variance in $\mathrm{FI}$ accounted by for each predictor when controlling for the other 
variables. These results indicated that $\mathrm{SN}\left(\Delta R^{2}=.28\right)$ was the most robust single predictor of $\mathrm{FI}$, followed by LA $\left(\Delta R^{2}=.08\right)$ and gender $\left(\Delta R^{2}=.02\right)$.

\section{Conclusions, Discussion, and Recommendations}

The population for this study was undergraduate students at the University of Arkansas during the Spring, 2020 academic semester. The accessible population included students in selected intact classrooms from either of two groups, agriculture courses and non-agriculture courses. Thus, the conclusions and recommendations from this study are limited to these respondents; caution should be used in generalizing to other groups.

The majority of respondents agreed availability of water as a resource will be negatively affected by a growing population and there is need to manage water as a finite natural resource. Interestingly, respondents indicated that they could do a better job at water use management, but that people close to them seemed to not care about water conservation and, therefore, did not practice conservation. The respondents felt that their personal water usage had little impact on water quantity and that they felt little societal pressure to conserve water. Thus, neither personal agency nor subjective norms appeared to provide incentives to value private-sphere water conservation behaviors.

When the students were asked if they would engage in future public-sphere water conservation behaviors, the majority indicated they would support water conservation programs, care more about water conservation, join a water conservation organization and support more strict water use legislation. Fewer than half of the respondents indicated that they would donate funds to support these efforts. Overall, these results indicate a fairly strong future intention to engage in public-sphere water conservation behaviors.

Analyses regarding which factors most contributed to respondents' FI regarding public-sphere water conservation revealed that gender, lack of agency, and subjective norms were significant predictors of $\mathrm{FI}$, explaining $36.7 \%$ of the variance. The finding related to gender does not agree with Koehler and Koontz (2008), who found males were more likely to engage in one specific type of public-sphere behavior (active participation in a cooperative watershed group). However, because Koehler and Koontz did not control for level of political involvement in their analysis, their finding of greater male participation in cooperative watershed groups may simply reflect males' higher level of involvement in local government entities (Leander et al., 2019), not a greater commitment to public-sphere water conservation behaviors. Further research is needed to better understand this relationship.

Previous research (Chaudhary et al., 2018; Larson et al., 2011) has found a significant negative relationship between conservative political orientation and private-sphere water conservation behaviors. The findings of this study are consistent with these previous studies and extend this relationship into public-sphere water conservation behaviors; however, the observed 
correlation was low (Davis, 1973) and political orientation did not enter into the regression equation.

The construct, subjective norms, made the greatest positive contribution to these students' $\mathrm{FI}$ to engage in public-sphere water conservation behaviors. This is consistent with previous research (Fielding et al., 2008; Pradhananga et al., 2015). According to Cislaghi and Heise (2018), determining the effects as opposed to the prevalence of social norms is important in guiding change-centered actions. This research established subjective norms as an important determinant of $\mathrm{Fl}$ to engage in public-sphere water conservation behaviors.

Lack of agency was a negative predictor of students' $\mathrm{FI}$ to engage in public-sphere water conservation behaviors. Intuitively, this makes sense because belief that circumstances are immutable logically leads to decreased motivation to act. This is consistent with findings by Martinez and McMullin (2004) that self-efficacy was a strong predictor of public-sphere environmental behaviors. In the broader literature, this is also supported by Jian and Jeffres (2008) who found greater political agency was associated with higher levels of political involvement.

If student attitudes and personal agency toward both private- and public-sphere water conservation behaviors can be positively affected during college, graduates are more likely to subsequently engage in these behaviors. One potential method of shaping these behaviors is by surrounding students with experiences and indicators that societal norms value water conservation behaviors. Providing on-campus experiences for students that clearly demonstrate positive societal norms about water conservation can provide the "focal points" (p. 1) around which subjective norms can be formed (Ensminger and Knight, 1997). In addition, publicizing positive outcomes of such initiatives may help to develop higher levels of personal and collective agency toward water conservation. To the extent this research informs practice, activities to promote water conservation behaviors among college students should focus on community-based interventions that shift subjective norms and agency towards water conservation.

\section{Acknowledgements}

This research was funded, in part, by the USDA National Institute of Food and Agriculture, Hatch project 1024473 and the University of Arkansas, Division of Agriculture.

\section{References}

Ajzen, I. (1991). The theory of planned behavior. Organizational Behavior and Human Decision Processes, 50(2), 179-211. https://doi.org/10.1016/0749-5978(91)90020-T

Andenoro, A. C., Baker, M., Stedman, N. L. P., \& Weeks, P. P. (2016). Research priority 7: Addressing complex problems. In T. G. Roberts, A. Harder, \& M. T. Brashears (Eds.). 
American Association for Agricultural Education national research agenda: 2016-2020. Department of Agricultural Education and Communication.

Arnocky, S., \& Stroink, M. L. (2011). Variation in environmentalism among university students: Majoring in outdoor recreation, parks, and tourism predicts environmental concerns and behaviors. Journal of Environmental Education, 42(3), 137-151. https://doi.org/10.1080/00958964.2010.516776

Brand, J. E. (2010). Civic returns to higher education: a note on heterogeneous effects. Social Forces, 89(2), 417-433. https://doi.org/10.1353/sof.2010.0095

Chaudhary, K. A., Lamm, A., \& Warner, L. (2018). Using cognitive dissonance to theoretically explain water conservation intentions. Journal of Agricultural Education, 59(4), 194210. https://doi.org/10.5032/jae.2018.04194

Chaudhary, A. K., Warner, L., Lamm, A., Israel, G., Rumble, J., \& Cantrell, R. (2017). Using the theory of planned behavior to encourage water conservation among extension clients. Journal of Agricultural Education, 58(3), 185-202. https://doi.org/10.5032/jae.2017.03185

Cislaghi, B., \& Heise, L. (2018). Theory and practice of social norms interventions: Eight common pitfalls. Global Health, 14(83), 2-10. https://doi.org/10.1186/s12992-018-0398-x

Clark, W. A., \& Finley, J. C. (2007). Determinants of water conservation intention in Blagoevgrad, Bulgaria. Society and Natural Resources, 20(7), 613-627. https://doi.org/10.1080/08941920701216552

Cohen, J. (1988). Statistical power analysis for the behavioral sciences (2nd ed.). Lawrence Erlbaum Associates, Inc.

Davis, J. A. (1971). Elementary survey analysis. Prentice-Hall.

Ensminger, J., \& Knight, J. (1997). Changing social norms: common property, bridgewealth, and clan exogamy. Current Anthropology, 38(1), 1-24.

Faul, F., Erdfelder, E., Lang, A. G., \& Buchner, A. (2007). G*Power 3: A flexible statistical power analysis program for the social, behavioral, and biomedical sciences. Behavior Research Methods, 39, 175-191. https://doi.org/10.3758/BF03193146

Field, A., \& Miles, J. (2012). Discovering statistics using SAS. Sage Publications, Ltd.

Fielding, K. S., McDonald, R., \& Louis, W. R. (2008). Theory of planned behavior, identity and intentions to engage in environmental activism. Journal of Environmental Psychology, 28(4), 318-326. https://doi.org/10.1016/j.jenvp.2008.03.003 
Hatcher, L. (1994). A step-by-step approach to using the SAS system for factor analysis and structural equation modeling. SAS Institute, Inc.

Koehler, B., \& Koontz, T. M. (2008). Citizen participation in collaborative watershed partnerships. Environmental Management, 41(2), 143-154. https://doi.org/10.1007/s00267-007-9040-z

Jian, G., \& Jeffres, L. (2008). Spanning the boundaries of work: workplace participation, political efficacy, and political involvement. Communication Studies, 59(1), 35-50. https://doi.org/10.1080/10510970701849370

Larson, K. L., \& Lach, D. (2010). Equity in urban water governance through participatory, placebased approaches. Natural Resources Journal, 50(2), 407-430. https://digitalrepository.unm.edu/cgi/viewcontent.cgi?article=1131\&context=nrj

Larson, K. L., Wutich, A., White, D., Munoz-Erickson, T. A., \& Harlan, S. L. (2011). Multifaceted perspectives on water risks and policies: A cultural domains approach in a southwestern city. Human Ecology Review, 18(1), 75-87. https://asu.pure.elsevier.com/en/publications/multifaceted-perspectives-on-waterrisks-and-policies-a-cultural-

Leander D. K., Gourrier, A. G., Bernick, E. L., \& Brekken, K. (2019). County governing boards: Where are all the women? Politics, Groups, and Identities, 7(1), 39-51. https://doi.org/10.1080/21565503.2017.1304223

Mancha, R. M., \& Yoder, C. Y. (2015). Cultural antecedents of green behavioral intent: An environmental theory of planned behavior. Journal of Environmental Psychology, 43, 145-154. https://doi.org/10.1016/i.jenvp.2015.06.005

Martinez, T. A., \& McMullin, S. L. (2004). Factors affecting decisions to volunteer in nongovernmental organizations. Environment and Behavior, 36(1), 112-126. https://doi.org/10.1177/0013916503256642

Pradhananga, A. K., Davenport, M., \& Olson, B. (2015). Landowner motivations for civic engagement in water resource protection. Journal of the American Water Resources Association, 51(6), 1600-1612. https://doi.org/10.1111/1752-1688.12346

Stern, P. C. (2002). Toward a coherent theory of environmentally significant behavior. Journal of Social Issues, 56(3), 407-424. https://doi.org/10.1111/0022-4537.00175

University of Arkansas. (2019). University of Arkansas student degree, enrollment and demographics [Data set]. https://oir.uark.edu/students/enrollment-reports/2020spring-report-v2.pdf 
United States Geological Survey. (2018). Estimated use of water in the United States in 2015.

(U.S. Geological Survey Circular No. 1441). https://pubs.er.usgs.gov/publication/cir1441

Yong, G., \& Pearce, S. (2013). A beginner's guide to factor analysis: focusing on exploratory factor analysis. Tutorials in Quantitative Methods for Psychology, 9(2), 79-94. https://doi.org/10.20982/tqmp.09.2.p079

(C) 2021 by authors. This article is an open access article distributed under the terms and conditions of the Creative Commons Attribution license (http://creativecommons.org/licenses/by/4.0/). 